\title{
Agronomic performance of Pera and related sweet orange accessions naturally infected with Citrus tristeza virus in northern Paraná State, Brazil
}

\author{
Viviane Y. Baba ${ }^{1}$, José S. Giampani ${ }^{2}$, Zuleide H. Tazima ${ }^{2}$, Inês F. U. Yada ${ }^{2}$, Luzia D. Paccola-Meirelles ${ }^{1} \&$ \\ Rui P. Leite Júnior ${ }^{2}$ \\ ${ }^{1}$ Universidade Estadual de Londrina, Rodovia Celso Garcia Cid, PR 445, Km 380, Cx. Postal 10011, 86057-970, Londrina, \\ Paraná, Brazil; 'Instituto Agronômico do Paraná, Rodovia Celso Garcia Cid, Km 375, 86047-902, Londrina, Paraná, Brazil
}

Author for correspondence: Rui Pereira Leite Júnior, e-mail: ruileite@iapar.br

\begin{abstract}
Despite of the susceptibility to the Citrus tristeza virus (CTV), Pera sweet orange is the most important citrus cultivar in Brazil. The objective of this study was to evaluate the CTV aggressiveness and the relationship with the agronomic performance of 24 accessions of Pera and related sweet oranges. Accessions belonging to the Citrus Germplasm Collection of the Instituto Agronômico do Paraná (IAPAR), Londrina, PR, were included in the study. Citrus tristeza disease was rated based on the severity of stem pitting symptoms. Yields were evaluated in the 2010/2011, 2011/2012, and 2012/2013 seasons, and tree growth in 2012. The best performance regarding stem pitting severity was shown by Redonda accession, followed by Ipiguá II. Vegetative tree vigor was more evident for Redonda, Tardia CO3, and Guilherme Spagnol accessions. These Pera and related sweet oranges accessions also showed the highest fruit yields, along with Vimusa, Santa Tereza, Ipiguá, Ipiguá II, D-6, and Paulo Rosa. Vegetative tree vigor, yield and number of fruits were inversely correlated with citrus tristeza disease stem pitting severity. Therefore, the poor agronomic performance of some Pera and related sweet oranges is probably related to the presence of severe CTV complexes infecting these accessions.
\end{abstract}

Key words: Citrus sinensis, cross protection, stem pitting, yield, vegetative tree vigor.

\section{INTRODUCTION}

The Brazilian citrus industry is one of the most economically important in the world, representing $26.4 \%$ of the world's production of sweet oranges (FAO, 2014). Several diseases including citrus variegated chlorosis (CVC), citrus blight, leprosis, citrus canker and Huanglongbing (HLB) (IBGE, 2014) constantly threaten citrus production in Brazil, which are concentrated in São Paulo State. Citrus areas are expanding in the State of Paraná, Brazil, especially in the North and Northwest regions of the State.

Pera sweet orange [Citrus sinensis (L.) Osbeck] is the most important citrus cultivar in Brazil, because of its multiple features and qualities (Salibe et al., 2002). Nevertheless, significant reduction in planting of Pera sweet orange occurred in recent years due to agronomic and crop health problems (Neves et al., 2010). The most challenging problem is the high susceptibility to citrus tristeza disease, caused by the Citrus tristeza virus (CTV)(Müller etal., 1999). The CTV (Family Closteroviridae: genus Closterovirus) is one of the most important citrus pathogens. Furthermore, CTV and its main vector, the brown citrus aphid (Toxoptera citricida Kirk.) are endemic in Brazil, thus sweet orange trees are most likely to be infected with this virus over their lifespan (Bordignon et al., 2003b).

In Brazil, the typical symptom of citrus tristeza disease in citrus is stem pitting, characterized by longitudinal depressions formed in the wood of the twigs, branches, and trunks. Citrus trees with severe stem pitting symptoms grow poorly, show lack of vigor, reduced leaf size, leaf chlorosis, low yield, and small and unmarketable fruits (Souza \& Müller, 2006; Dawson et al., 2013).

The control of citrus tristeza disease in Pera sweet orange has been possible through cross-protection with mild strains of CTV (Teófilo Sobrinho et al., 2001). Grant \& Costa (1951) observed that citrus trees infected with mild strains of CTV were protected against infection by severe strains of the virus. Therefore, the cross protection technique became a basic and widely used measure to control citrus tristeza disease in Pera sweet orange in Brazil (Costa \& Müller, 1980).

The planting of Pera sweet orange trees that are cross-protected against CTV are key for the success of the Brazilian citrus industry, where more than 90 million crossprotected trees of Pera sweet orange have been planted (Moreno et al., 2008). However, CTV is a continuous threat due to the risk of introduction of new severe CTV strains or strain complexes (Folimonova, 2013); the endemic 
presence of $T$. citricida, which is the most efficient vector for CTV transmission (Bordignon et al., 2003b; Moreno et al., 2008); and the use of a single mild strain of the virus in the cross protection programs (Müller et al., 1999).

In the State of Paraná, Brazil, changes have been identified in the CTV protective complex in use and also the presence of severe strains of the virus in different accessions of Pera sweet orange (Carraro et al., 2003; Costa et al., 2010; Corazza et al., 2012; Zanutto et al., 2013). Therefore, accessions of cross-protected mother trees introduced from other regions of Brazil or naturally infected selected trees may not perform well in the presence of the citrus tristeza disease in Paraná (Corazza et al., 2012; Zanutto et al., 2013).

The objectives of this study were to evaluate the response of Pera and related sweet oranges accessions to CTV complex present in the Northern region of the State of Paraná, Brazil, and to determine the correlation between severity of citrus tristeza disease symptoms and agronomic performance of the accessions.

\section{MATERIALS AND METHODS}

\section{Plant material}

Twenty-two accessions of Pera and two accessions of related sweet oranges (I-79 Redonda and I-86 Umbigo), grafted on the rootstock Rangpur lime (Citrus limonia Osbeck), from the Citrus Germplasm Collection (CGC) of the Instituto Agronômico do Paraná - IAPAR, were evaluated in regard to citrus tristeza disease. The CGC was established in the Experimental Station of IAPAR, Londrina, PR, Brazil, on a Typic Hapludox soil, at the latitude of $23^{\circ} 21^{\prime} 50^{\prime \prime} \mathrm{S}$, longitude of $51^{\circ} 10^{\prime} 25^{\prime \prime} \mathrm{W}$ and altitude of $585 \mathrm{~m}$. The climate is classified as Cfa type (Caviglione et al., 2000) with average annual temperatures of $27.3^{\circ} \mathrm{C}$ (max.) and $16.0^{\circ} \mathrm{C}$ (min.) (IAPAR, 2014). The annual average rainfall is $1,608 \mathrm{~mm}$ and the relative humidity is $70.5 \%$ (IAPAR, 2014).

The trees were planted on June 2000 in a spacing of $7.0 \times 6.0 \mathrm{~m}$ without irrigation. The experimental design was completely randomized, with 24 treatments and three replicates for each treatment. The sweet orange accessions included in the study were originally introduced from other research institutions in Brazil and also collected in orchards in the State of Paraná. These accessions were naturally infected with CTV. The virus infection was confirmed by using the technique of Bi-Directional - Reverse Transcription - Polymerase Chain Reaction (BD-RTPCR) for amplification of the p23 protein, as described by Sambade et al. (2013). The trees were inspected regularly for other citrus diseases such as CVC and HLB. The citrus trees were grown according to the cultural and plant protection practices recommended for the Northern region of the State of Paraná, Brazil (IAPAR, 1992).

\section{Assessment of severity of stem pitting symptoms}

The Pera and related sweet oranges accessions were evaluated for the severity of stem pitting symptoms caused by the CTV complex from August to November of 2011. Eight circular and lignified branches of 0.5 to $1.0 \mathrm{~cm}$ in diameter and $15 \mathrm{~cm}$ long were collected from the middle part of each quadrant of the citrus tree. The branches were autoclaved at $120^{\circ} \mathrm{C}$ for five minutes in order to facilitate the removal of the bark. Stem pitting severity was determined by using a diagrammatic scale ranging from 0 to 5 , adapted from Meissner Filho et al. (2002), as follow: $0=$ absence of stem pitting; $1=$ rare surface stem pitting; $2=$ sparse moderate surface stem pitting; $3=$ shallow stem pitting to an intermediate degree, rarely deep; $4=$ large amount of surface and deep stem pitting; and $5=$ branch completely covered with stem pitting.

\section{Evaluations of the yield and tree growth}

The size and number of fruits of each tree, and the total yield for the 2010/2011, 2011/2012 and 2012/2013 seasons were determined. The fruits were sorted according to the size with the aid of wood boards, with openings of 54,64 , and $73 \mathrm{~mm}$ in diameter. All fruits were classified in four size categories: very small $(<54 \mathrm{~mm})$, small $(54$ $64 \mathrm{~mm})$, medium $(64-73 \mathrm{~mm})$, and large $(>73 \mathrm{~mm})$. After sorting by size, the total number of fruits by category was determined.

The tree growth was determined in August 2012. The trees were evaluated for the height $(\mathrm{m})$ and canopy diameter $(\mathrm{m})$ with a graduated scale. The trunk diameter was measured at $10 \mathrm{~cm}$ below and above the grafting line. The vegetative tree vigor index was calculated by using the equation: $\mathrm{V} 1=[$ height $(\mathrm{m})+$ average diameter of the canopy $(\mathrm{m})+($ diameter below the grafting line $(\mathrm{cm}) / 100$ $\times 10)$ ] (Bordignon et al., 2003b). The canopy volume was calculated using the equation: V2 $=2 / 3 \cdot \pi \cdot R^{2} \cdot H$ (Mendel, 1956), in which V2 is the volume of the canopy $\left(\mathrm{m}^{3}\right)$; $\mathrm{R}$ is the average radius of the canopy $(\mathrm{m})$; and $\mathrm{H}$ is the tree height (m). The canopy conformation index was calculated based on the ratio of the height of the tree and the diameter of the canopy. The yield efficiency index $\left(\mathrm{Kg} / \mathrm{m}^{3}\right)$ was determined based on the ratio of the average annual yield $(\mathrm{kg} / \mathrm{tree})$ and canopy volume $\left(\mathrm{m}^{3}\right)$.

\section{Statistical analysis}

Data of stem pitting severity, yield, and tree growth index were subjected to ANOVA and Scott-Knott test, at $5 \%$ significance level. The percentage of fruits per size category $(<54,54-64,64-73$, and $>73 \mathrm{~mm})$ was transformed in arcsine square root $\times / 100$ for statistical analysis, and subjected to both Pearson's linear correlation and $t$-test by using the Statistical Analysis System-SAS program (SAS Institute, 2009).

\section{RESULTS}

Based on the stem pitting severity assessments, the Pera and related sweet oranges accessions were classified into five groups (Table 1). The accession I-79 Redonda 


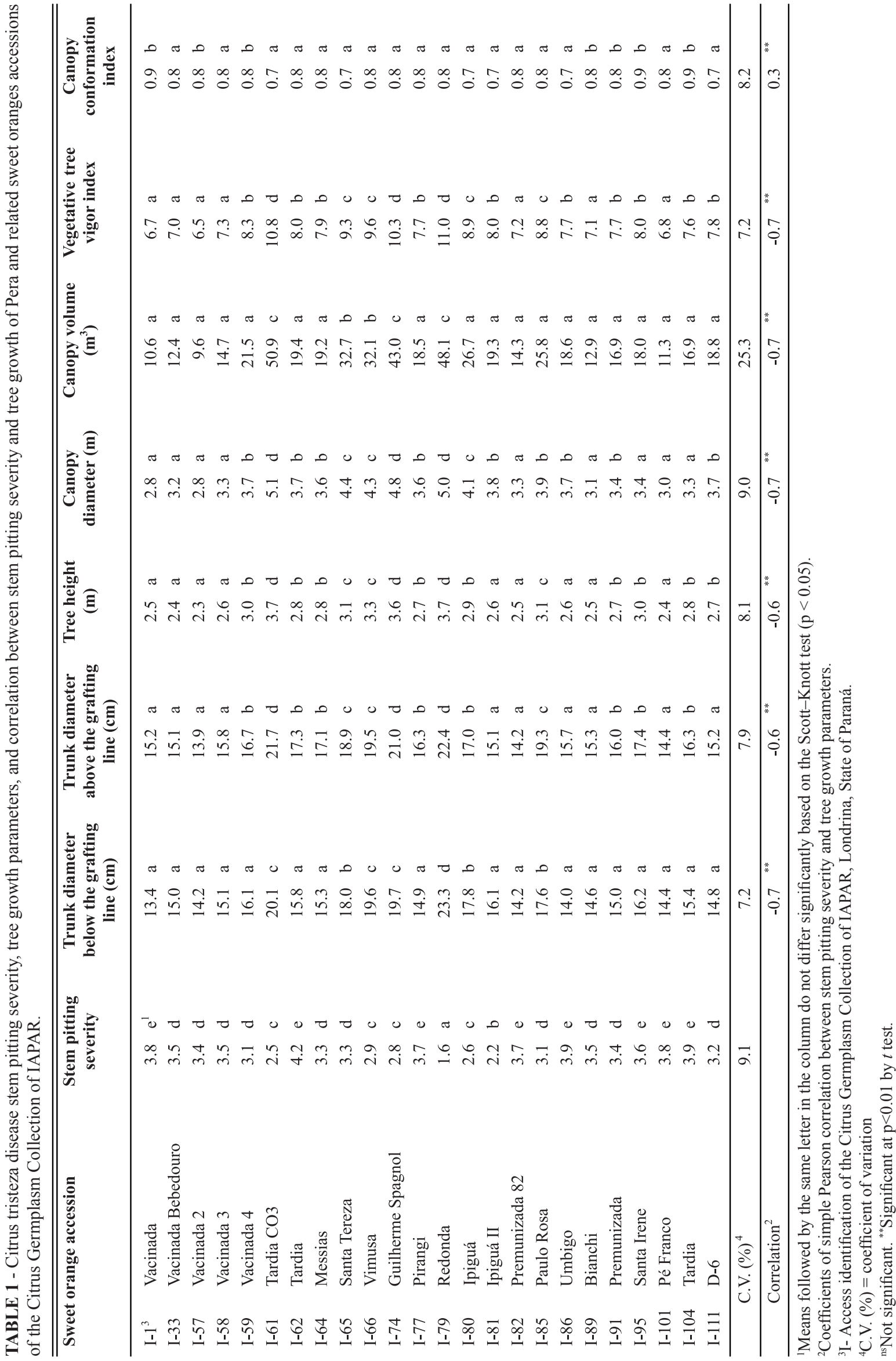


Agronomic performance of Pera and related sweet orange accessions naturally infected with...

showed the lowest disease severity index, followed by the accession I-81 Ipiguá II (Table 1). In contrast, the accessions I-62 Tardia, I-104 Tardia, I-86 Umbigo, I-1 Vacinada, I-101 Pé Franco, I-77 Pirangi, I-82 Premunizada 82, and I-95 Santa Irene showed the highest stem pitting levels (Table 1). Based on the BD-RT-PCR test, all accessions were infected with CTV. However, this technique does not allow differentiating the virus complexes. Most trees showed characteristic fragments of the severe, mild and atypical groups of CTV, based on the classification of Sambade et al. (2003). Therefore, a high diversity of this virus complex may be present in the sweet orange trees included in this study (data not shown).

The growth of the citrus trees showed significant differences among the accessions included in the study, and they were classified into four distinct groups (Table 1). The group with the highest tree growth based on the vegetative tree vigor index included the accessions I-79 Redonda, I-61 Tardia CO3, and I-74 Guilherme Spagnol (Table 1). The second group that presented large tree growth included the accessions I-66 Vimusa, I-65 Santa Tereza, I 80 Ipiguá, and I-85 Paulo Rosa (Table 1).

The results obtained indicated that the accessions I-79 Redonda, I-61 Tardia CO3, and I-74 Guilherme Spagnol had the largest height, followed by I-66 Vimusa, I-65 Santa Tereza, and I-85 Paulo Rosa (Table 1). Similarly, these accessions presented the largest canopy volumes, with the exception of I-85 Paulo Rosa, which showed the smallest canopy volume (Table 1). On the other hand, tree development of the accessions I-89 Bianchi and I-58 Vacinada 3 were among the smallest with 12.86 and 14.65 $\mathrm{m}^{3}$ of canopy volume, respectively (Table 1 ).

The yields of the orange trees were evaluated for three seasons, 2010/2011, 2011/2012, and 2012/2013. The accession I-79 Redonda had the highest yield, followed by the accessions I-61 Tardia CO3, I-66 Vimusa, I-65 Santa Tereza, I-80 Ipiguá, I-81 Ipiguá II, I-74 Guilherme Spagnol, I-111 D-6, and I-85 Paulo Rosa (Table 2). In relation to fruit weight, I-86 Umbigo produced the largest fruits, followed by I-74 Guilherme Spagnol, I-111 D-6, I-79 Redonda, I-59 Vacinada 4, I-61 Tardia CO3, I-58 Vacinada 3, and I-89 Bianchi (Table 2).

The yield efficiency, which is a parameter that establishes the yield by canopy volume, was significantly higher for the accession I-81 Ipiguá II, followed by I-111 D-6, I-57 Vacinada 2, I-80 Ipiguá, and I-79 Redonda (Table 2). The data obtained in this study showed that the accessions I-89 Bianchi, I-58 Vacinada 3, and I-59 Vacinada 4 had a poor performance when compared to other important accessions in terms of tree development and yield.

The stem pitting severity data were negatively and significantly correlated with the majority of the agronomic parameters of the Pera and related sweet oranges accessions, except for the percentage of fruits in the size categories of 54-64 mm and $>73 \mathrm{~mm}$ (Tables 1 and 2). The highest correlations were observed for the parameters yield $(-0.8)$, number of fruits $(-0.8)$, and vegetative tree vigor index $(-0.7)$. Therefore, citrus tristeza disease stem pitting symptoms were inversely correlated with yield, number of fruits and vegetative tree vigor index. Therefore, these data suggest that the low agronomic performance of some Pera and related sweet oranges accessions may be due to the severity of the CTV complex present in the tree.

\section{DISCUSSION}

The lowest severity of citrus tristeza disease symptoms was observed in the accession I-79 Redonda, which has been considered a non-true type of Pera sweet orange (Domingues et al., 1999). However, accessions of Pera sweet orange with good agronomic performance in Northern Paraná (Tazima et al., 2010), such as I-58 Vacinada 3, I-59 Vacinada 4, and I-89 Bianchi, showed severe stem pitting symptoms due to citrus tristeza disease. The severity of stem pitting observed for some accessions of Pera sweet orange in this study differed from those reported by Costa et al. (2010), that evaluated citrus tristeza disease severity in several different clones of Pera, also in an experimental orchard in the Northern region of the State of Paraná, Brazil. According to these authors, Pera Bianchi $89 \mathrm{C}$ showed milder symptoms of stem pitting, whereas more severe symptoms were observed for Pera Seleção 37 and Pera Vimusa 66 B. Further, Temporal et al. (2011) observed severe CTV symptoms in Pera Bianchi 89 C, Pera Vacinada $59 \mathrm{~B}$, and Pera Vacinada $58 \mathrm{~B}$ in an experimental orchard in the municipality of Arapongas, located also in the Northern region of the State of Paraná. These differences may be due to the presence of different CTV haplotypes, in combination with differences in sensibility of plant tissues to the virus.

Symptoms of stem pitting are typical of Pera sweet orange infected with CTV, including in those trees crossprotected with mild strains of the virus (Salibe et al., 2002). Further, these symptoms are more severe in areas with mild climate (Koller \& Soprano, 1998; Salibe et al., 2002). Despite of environmental conditions, symptoms of CTV infection in Pera sweet orange may also vary according to the aggressiveness of the viral complex and the sensibility or phenotypic features of the citrus cultivar. Considering an increase in severity of citrus tristeza disease symptoms in 'Valencia' sweet orange trees, Koller \& Soprano (1998) raised the possibility of gradual replacement of mild strains of the virus by severe strains of CTV. Recently, Costa et al. (2010) identified genetic changes in CTV isolates from Pera sweet orange accessions of the CGC of IAPAR, as in Pera D-6 111A (D-6-I) and Pera Vimusa 66B (V-I) accessions. These changes may have occurred due to genetic segregation of the virus after repeated propagations of plant material or contamination of the trees in the nursery (Costa et al., 2010).

The vegetative tree vigor index, which involves tree height, canopy diameter, and trunk diameter, seems to be the parameter that best reflects the vegetative growth 


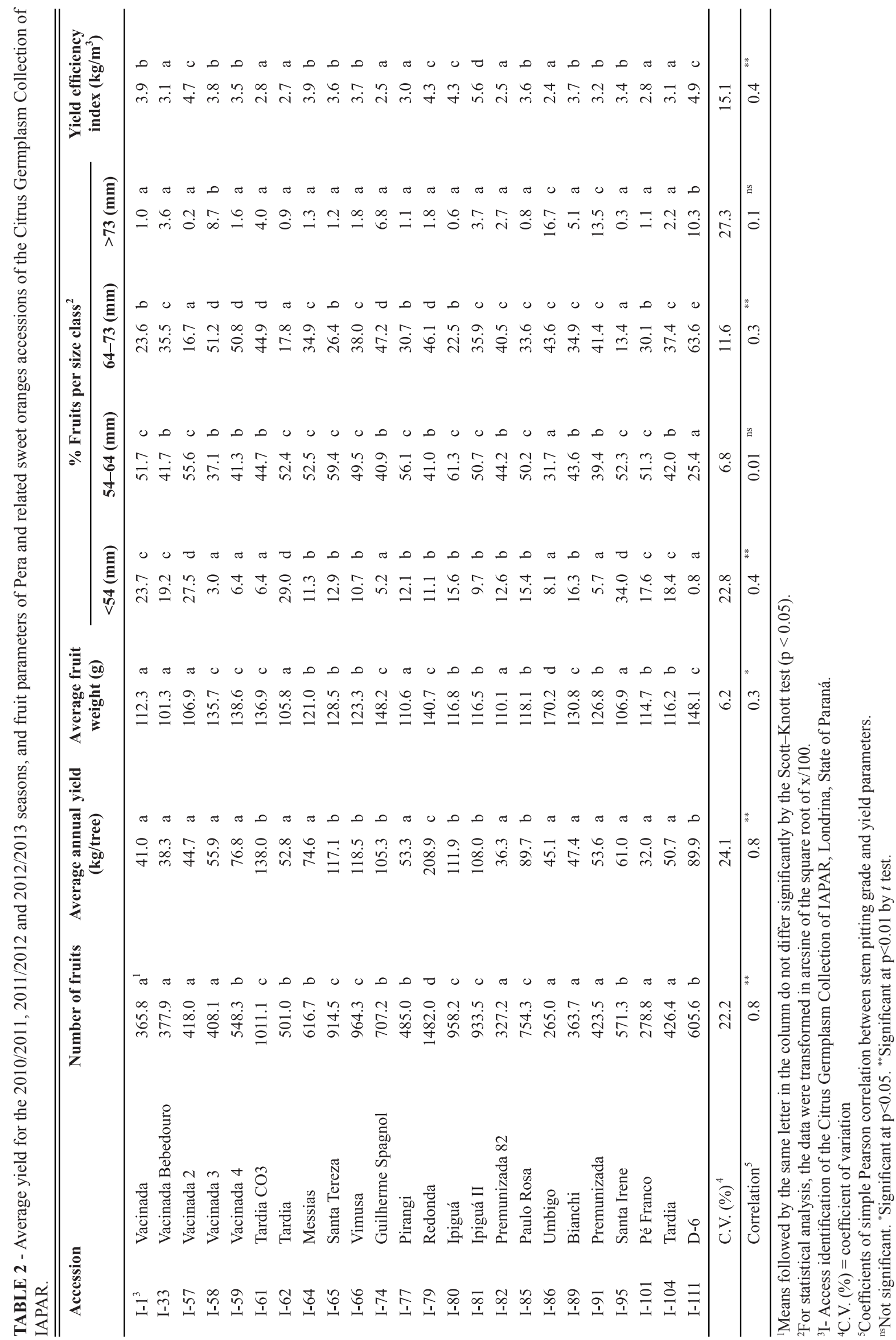


Agronomic performance of Pera and related sweet orange accessions naturally infected with...

of the trees, as described by Bordignon et al. (2003a). In the present study, the accessions I-79 Redonda, I-61 Tardia CO3, and I-74 Guilherme Spagnol had the best vegetative tree vigor index. Furthermore, the vegetative growth of these accessions confirmed the results obtained by Domingues et al. (2004) in a study carried out in Cordeirópolis, State of São Paulo. According to these authors, Pera GS 2000 sweet orange trees showed the highest height, followed by Redonda and Vimusa. The results of our study indicated that the accessions I-79 Redonda, I-74 Guilherme Spagnol, and I-61 Tardia CO3 were the highest, followed by I-66 Vimusa, and I-115 Umbigo. In terms of canopy volume, our results were similar to those obtained by Domingues et al. (2004), as the accession I-79 Redonda had a canopy volume around $48 \mathrm{~m}^{3}$ and did not differ from the I-74 Guilherme Spagnol.

The yields of the different accessions included in this study were lower than expected. According to Figueiredo (1991), the estimated yield for Pera sweet orange in the State of São Paulo, Brazil, is $250 \mathrm{~kg}$ per tree, which is much higher than the yield obtained in our study. Tazima et al. (2010), evaluating the yield and quality of fruits of I-58 Vacinada 3, I-59 Vacinada 4, and I-89 Bianchi accessions, under the conditions of Londrina, State of Paraná, reported an annual yield of 164.10, 133.96 , and $131.03 \mathrm{~kg}$ per tree for these accessions, respectively. In fact, the agronomic performance of the citrus tree largely depends on the local environmental conditions and horticultural practices, as well as on the CTV complex present in the tree.

The high negative correlation between the severity of stem pitting symptoms and the parameters yield, number of fruits, and vegetative tree vigor index may be an indicative of the aggressiveness of the CTV complex infecting the Pera sweet orange trees evaluated in this study. Similar results were obtained by Bordignon et al. (2003b) evaluating the effect of CTV infection on vegetative growth, yield, and industrial variables of Valencia sweet orange trees. They observed that the yield was the most affected parameter, with $85 \%$ reduction in cumulative yield for five seasons. In general, the production variables (i.e., fruit mass and yield) were the most affected, followed by vegetative variables (i.e., vegetative tree vigor, tree height, and trunk diameter), whereas the industrial variables were minimally affected (Bordignon et al., 2003b).

The results of the present study indicated that aggressiveness of the CTV complex, based on stem pitting severity, is strongly negative correlated with the agronomic performance of Pera and related sweet oranges accessions under the condition of the Northern region of the State of Paraná. Further detailed studies should be carried out to better characterize the CTV complexes that are present in the State of Paraná. This information is of utmost importance to improve the efforts in the CTV cross protection programs for these and others sweet oranges accessions, as well as to enhance tree growth and productivity.

\section{ACKNOWLEDGMENTS}

The Instituto Agronômico do Paraná - IAPAR is acknowledged for providing infrastructure and support, the Fundação Araucária de Apoio ao Desenvolvimento Científico e Tecnológico do Paraná for financial support and the Conselho Nacional de Desenvolvimento Científico e Tecnológico - CNPq for providing a scholarship.

\section{REFERENCES}

Bordignon R, Medina Filho HP, Siqueira WJ, Pio RM (2003a) Características da laranjeira 'Valência' sobre clones e híbridos de porta-enxertos tolerantes à tristeza. Bragantia 62:381-395.

Bordignon R, Medina Filho HP, Siqueira WJ, Pio RM (2003b) Efeito da tristeza em caracteres vegetativos, produtivos e industriais da laranjeira 'Valência' enxertada em híbridos segregando para tolerância. Bragantia 62:207-215.

Carraro BP, Nunes WMC, Corazza-Nunes MJ, Machado MA, Stach-Machado DR (2003) Avaliação de complexos do Citrus tristeza virus da região Norte do Paraná por meio de testes imunológicos e SSCP do gene da capa protéica. Acta Scientiarum 25:269-273.

Caviglione JH, Kiihl LRB, Caramori PH, Oliveira D (2000) Cartas climáticas do Paraná. Londrina, PR. IAPAR. CD-ROM.

Corazza MJ, Zanutto CA, Zanineli-Ré ML, Müller GW, Nunes WMC (2012) Comparison of Citrus tristeza virus (CTV) isolates by RFLP analysis of the coat protein nucleotide sequences and by the severity of the symptoms. Tropical Plant Pathology 37:179184.

Costa AS, Müller GW (1980) Tristeza control by cross protection: a US-Brazil cooperative success. Plant Disease 64:538-541.

Costa AT, Nunes WMC, Zanutto CA, Müller GW (2010) Stability of Citrus tristeza virus protective isolates in field conditions. Pesquisa Agropecuária Brasileira 45:693-700.

Dawson WO, Garnsey SM, Tatineni S, Folimonova SY, Harper SJ, Gowda S (2013) Citrus tristeza virus-host interactions. Frontiers in Microbiology 4:88.

Domingues ET, Teófilo Sobrinho J, Tulmann Neto A, Mattos Junior D (1999) Seleção de clones de laranja 'Pêra' e variedades assemelhadas quanto à qualidade do fruto e ao período de maturação. Laranja 20:433-455.

Domingues ET, Teófilo Sobrinho J, Pompeu Júnior J, Figueiredo JO De, Tulmann Neto A (2004) Caracterização de onze clones de laranja 'Pêra' e seis variedades assemelhadas. Laranja 25:111138.

FAO - Food and Agriculture Organization of the United Nations. Statistics: FAOSTAT Domains/Production/Crops. Available at:faostat3.fao.org/faostat-gateway/go/to/download/Q/QC/E. Accessed on April 4, 2014.

Figueiredo JO (1991) Variedades copa de valor comercial. In: 
Rodriguez O, Viégas FCP, Pompeu Junior J, Amaro AA (Eds.) Citricultura Brasileira. 2nd Ed. Campinas, SP, Brazil. Fundação Cargill. pp. 228-264.

Folimonova SY (2013) Developing an understanding of crossprotection by Citrus tristeza virus. Frontiers in Microbiology 4:76.

Grant TJ, Costa AS (1951) A mild strain of the tristeza virus of citrus. Phytopathology 41:114-122.

IAPAR - Instituto Agronômico do Paraná. Agrometeorologia. Estações Meteorológicas. Médias Históricas. Available at: www. iapar.br/arquivos/Image/monitoramento/Medias_Historicas/ Londrina.htm. Accessed on April 4, 2014.

IAPAR (1992) A citricultura do Paraná. Londrina, PR. IAPAR. (Circular Técnica, 72)

IBGE-Instituto Brasileiro de Geografia e Estatística. Levantamento Sistemático da Produção Agrícola. Available at: ftp.ibge.gov.br/ Producao_Agricola/Levantamento_Sistematico_da_Producao_ Agricola_\%5Bmensal\%5D/Fasciculo/lspa_201402.pdf. Accessed on April 4, 2014.

Koller OL, Soprano E (1998) Aumento na severidade do vírus da tristeza dos citros em dois clones de laranja 'Valência'. Ciência e Agrotecnologia 22:219-225

Meissner Filho PE, Soares Filho W Dos S, Velame KVC, Diamantino EP, Diamantino MSAS (2002) Reação de portaenxertos híbridos ao Citrus tristeza virus. Fitopatologia Brasileira 27:312-315.

Mendel K (1969) Rootstock-scion relationships in Shamouti treeson light soil. Ktavim, Rehovot 6:35-60.

Moreno P, Ambrós S, Albiach-Martí MR, Guerri J, Peña L (2008) Citrus tristeza virus: a pathogen that changed the course of the citrus industry. Molecular Plant Pathology 9:251-268.
Müller GW, Targon MLN, Machado MA (1999) Trinta anos de uso do clone pré- imunizado "Pêra" IAC na citricultura paulista. Laranja 20:399-408.

Neves MF, Trombin VG, Milan P, Lopes FF, Cressoni F, Kalaki R (2010) O Retrato da Citricultura Brasileira. Available at: www. citrusbr.com.br/download/Retrato_Citricultura_Brasileira Marcos_Fava.pdf. Accessed on May 26, 2014.

Sambade A, López C, Rubio L, Flores R, Guerri J, Moreno P (2003) Polymorphism of a specific region in the gene p23 of Citrus tristeza virus allows discrimination between mild and severe isolates. Archives of Virology 148:2325-2340.

Salibe AA, Teófilo Sobrinho J, Müller GW (2002) Sinopse de conhecimentos e pesquisas sobre a laranja 'Pêra'. Laranja 23:231245.

SAS Institute (2009) SAS/STAT: User's Guide. Version 9.2 Cary, NC, EUA. SAS Institute Inc.

Souza AA, Müller GW (2006) A premunização no controle da tristeza dos citros. Laranja 27:57-70.

Tazima ZH, Neves CSVJ, Yada IFU, Leite Júnior RP (2010) Produção e qualidade dos frutos de clones de laranjeira- 'Pêra' no norte do Paraná. Revista Brasileira de Fruticultura 32:189-195.

Temporal WM, Corazza MJ, Zanutto CA, Nunes WMC, Müller GW (2011) SSCP analysis of Citrus tristeza virus protective isolates in Pêra sweet orange clones under northern Paraná state, Brazil conditions. Citrus Research \& Technology 32:9-16.

Teófilo Sobrinho J, Müller GW, Figueiredo JO De, Laranjeira FF, Salibe AA (2001) Laranja- 'Pêra IAC 2000'. Laranja 22:495-501.

Zanutto CA, Corazza MJ, Nunes WMC, Müller GW (2013) Evaluation of the protective capacity of new mild Citrus tristeza virus (CTV) isolates selected for a preimmunization program. Scientia Agricola 70:116-124. 